\title{
Strategic evaluation of the Food and Nutrition Security Plan of the State of Santa Catarina, Brazil
}

\section{Avaliação Estratégica do Plano de Segurança Alimentar e Nutricional de Santa Catarina}

\author{
Mick Lennon MACHADO1 ${ }^{1}$ (D) 0000-0001-7550-1692 \\ Cristine Garcia GABRIEL ${ }^{1}$ (iD) 0000-0002-5413-0826 \\ Josimari Telino de LACERDA² (DD 0000-0002-1992-4030 \\ Patrícia Maria de Oliveira MACHADO² (iD) 0000-0002-8630-8318
}

\section{A B S T R A C T}

\section{Objective}

A strategic analysis was carried out in order to verify the relevance of the Food and Nutrition Security Plan of the state of Santa Catarina to the Brazilian concept of Food and Nutrition Security.

\section{Methods}

A matrix containing 7 dimensions, 16 sub-dimensions and 35 indicators was used for the evaluation, which were evaluated as poor, regular, good and excellent for each component.

\section{Results}

The Plan was evaluated as being of good relevance to its objective. However, it was only relevant to $53 \%$ of the analyzed dimensions, and the dimension of promoting universal access to adequate food had the worst result. The dimensions of developing permanent processes of education, research and training, and of evaluation and

${ }^{1}$ Universidade Federal de Santa Catarina, Centro de Ciências da Saúde, Programa de Pós-Graduação em Nutrição. Campus Universitário Reitor João David Ferreira Lima, s/n., Trindade, 88040-900, Florianópolis, Santa Catarina, Brasil. Correspondência para/Correspondence to: CG GABRIEL. E-mail: <cristine.gabriel@ufsc.br>

2 Universidade Federal de Santa Catarina, Centro de Ciências da Saúde, Programa de Pós-Graduação em Saúde Coletiva. Florianópolis, SC, Brasil.

Support: Ministério do Desenvolvimento Social, by the public Notice 01/2013.

Article based on the thesis by ML MACHADO, entitled "Avaliação do Plano Estadual de Segurança Alimentar e Nutricional de Santa Catarina". Universidade Federal de Santa Catarina; 2017.

Como citar este artigo/How to cite this article

Machado ML, Gabriel CG, Lacerda JT, Machado PMO. Strategic evaluation of the Food and Nutrition Security Plan of the State of Santa Catarina, Brazil. Rev Nutr. 2018;31(6):617-30. http://dx.doi.org/10.1590/1678-98652018000600010 
monitoring, obtained the best results, with the Plan being evaluated as of good relevance to these dimensions. Still, for half of the sub-dimensions and for $60 \%$ of the analyzed indicators, the Plan was evaluated as poor or regular.

\section{Conclusion}

It is hoped that the results of this research can qualify the Plan researched, as well as stimulate reflections for the construction of Plans in the other Brazilian states.

Keywords: Evaluation Studies. Food and Nutrition Security. Public Policy.

\section{RE S U M O}

\section{Objetivo}

Realizou-se pesquisa avaliativa, do tipo análise estratégica, para verificar a pertinência do Plano de Segurança Alimentar e Nutricional de Santa Catarina ao conceito brasileiro de Segurança Alimentar e Nutricional.

\section{Métodos}

Para a avaliação, foi utilizada uma matriz contendo 7 dimensões, 16 subdimensões e 35 indicadores, avaliados segundo os juízos de valor ruim, regular, bom e ótimo para cada componente.

\section{Resultados}

O Plano foi avaliado como de boa pertinência ao seu objetivo. No entanto, apresentou pertinência apenas regular para 53\% das dimensões analisadas, sendo que a dimensão de promoção do acesso universal à alimentação adequada obteve o pior resultado. As dimensões de instituição de processos permanentes de educação, pesquisa e formação, e de avaliação e monitoramento, obtiveram os melhores resultados, sendo o Plano avaliado como de boa pertinência a estas dimensões. Ainda, para metade das subdimensões e $60 \%$ dos indicadores analisados, o Plano obteve avaliação ruim ou regular.

\section{Conclusão}

Espera-se que os resultados desta pesquisa possam qualificar o Plano pesquisado, bem como estimular reflexões para construção de Planos nos demais estados brasileiros.

Palavras-chave: Estudos de Avaliação. Segurança Alimentar e Nutricional. Política Pública.

\section{NTRO D U CTION}

The multidimensionality of the concept of Food and Nutrition Security adopted by Brazil imposes challenges for the implementation of an inherently intersectoral public policy. In addition, it exposes the necessity to think of evaluative strategies that can respond by their amplitude, through indicators and by methodologies and instruments of comprehensive and systemic information collection [1].

The concept of Food and Nutrition Security in Brazil incorporates dimensions related to quantity and quality, including the right of access to food, guaranteed food production with sustainable practices, conservation and control of the genetic basis of the agri-food system, agricultural supply, sanitary and nutritional quality, citizenship and human rights [2-7]. In this perspective, efforts have been applied to systematize dimensions and list indicators capable of responding to the concept in question, considering that reducing nutrition to its nutritional dimension means limiting the human being to its biologicity, while considering only the economic condition or food availability means subjecting the whole food process to market laws [8].

In spite of this, there have been many studies that evaluate Food and Nutrition Security in Brazil, essentially at the individual or family level and usually involving few dimensions. At the same time, there are few evaluative studies on the aspects of management and execution of the Política Nacional de Segurança Alimentar e Nutrição (PNSAN, National Policy on Food and 
Nutrition Security) and the Sistema Nacional de Segurança Alimentar e Nutricional (SISAN, National System of Food and Nutrition Security).

Food and Nutrition Security Plans (PlanSAN) are the main planning, management and implementation tools of the National Policy for Food and Nutrition Security [9], and express management commitments agreed with civil society. They must be prepared by all states and municipalities that have adhered to the National System of Food and Nutrition Security, and organized starting from a set of objectives, goals and actions that seek to guarantee Food and Nutrition Security and allow the public authority to fulfill its duty in guaranteeing the right of all human beings to have proper food intake $[9,10]$.

Although all states have, since 2014, already been members of the National System of Food and Nutrition Security, at the time of this survey only Santa Catarina, Bahia and Paraíba had a plan in action [1]. Of these, the Plan of Santa Catarina (State of Santa Catarina Food and Nutrition Security Plans), published in 2014 and valid until 2019, was the best evaluated in relation to the normative aspects [1]. Considering the importance of carrying out other evaluations to ensure that the Plans meet their objective in the National Policy for Food and Nutrition Security, this article carries out a strategic evaluation to analyze the degree to which the State of Santa Catarina Food and Nutrition Security Plans is accountable for Food and Nutrition Security, subsidizing reflections and orientations about the National Policy for Food And Nutrition Security management.

\section{METHODS}

This research was performed between the September 2016 and April 2017. It is an evaluative research of strategic analysis that seeks to verify the pertinence of an intervention in confronting a given problem or situation [11]. Relevance is understood here as "the ability of an intervention to provide answers to the problems faced by decision-makers" [12]. In the present study, it is assumed that the State of Santa Catarina Food and Nutrition Security Plan is the instrument of the National Policy on Food and Nutrition Security in the state of Santa Catarina that gathers the answers to face the problems related to Food and Nutrition Security in this territory. The option for the specific evaluation of the Plan of Santa Catarina occurred because it is the Plan with the best evaluation in relation to the normative aspects, among the three plans performed in the study period [1].

Through a literature and document review, considering the legal frameworks of the National Policy for Food and Nutrition Security, a proposal was prepared for an evaluation matrix of the State Food and Nutrition Security Plans, composed of dimensions, sub-dimensions, indicators and measures that, at first, was agreed upon in two consensus workshops with the research group. The internally agreed matrix was sent to a group of external experts, using the Delphi method, which seeks a collective consensus on certain issues, without face-to-face contact and guaranteeing the anonymity of the participants [13]. Among the participants there were 8 specialists, whose contributions were used to adjust the final version of the matrix, composed of 7 dimensions, 16 sub-dimensions, 35 indicators and 99 measures (Table 1).

Documentary data collection regarding the State of Santa Catarina Food and Nutrition Security Plan was performed during the month of February, 2017. With a detailed reading of the document, paying special attention to the goals and actions, it was possible to verify if the State of Santa Catarina Food and Nutrition Security Plans met each of the measures. For this analysis, a possible set of answers was elaborated for each measure, allowing the evaluation of whether the goals and actions of the State of Santa Catarina Food and Nutrition Security Plans were completely fulfilled (grade given: 10-ten) or not (grade given: 0-zero). The measures partially met received a decimal 
Table 1. Summary table of the evaluative matrix of State Plans of Food and Nutrition Security. Santa Catarina (SC), Brazil, 2017.

\begin{tabular}{|c|c|c|c|}
\hline Dimensions & Sub-dimensions & Indicators & $\begin{array}{c}\mathrm{n}^{\circ} \text { of } \\
\text { measures }\end{array}$ \\
\hline \multirow{5}{*}{$\begin{array}{l}\text { Promotion of universal } \\
\text { access to adequate food }\end{array}$} & $\begin{array}{l}\text { Prioritization of populations in } \\
\text { situations of social vulnerability }\end{array}$ & $\begin{array}{l}\text { Flow of attention to populations in social } \\
\text { vulnerability }\end{array}$ & 3 \\
\hline & Income & Generation of employment and income & 5 \\
\hline & Tax adjustment & $\begin{array}{l}\text { Tax incentive in the production/consumption of } \\
\text { adequate food }\end{array}$ & 3 \\
\hline & \multirow[t]{2}{*}{ Distribution of food and meals } & $\begin{array}{l}\text { Execution of programs for distributing food and } \\
\text { meals }\end{array}$ & 4 \\
\hline & & $\begin{array}{l}\text { Availability of Food and Nutrition Security public } \\
\text { equipment }\end{array}$ & 2 \\
\hline \multirow{8}{*}{$\begin{array}{l}\text { Structuring agroecological } \\
\text { production systems and } \\
\text { sustainable food supply }\end{array}$} & \multirow[t]{2}{*}{ Access to land } & Landholding and land regularization & 2 \\
\hline & & Agrarian reform & 1 \\
\hline & Production Incentive & Qualification and Technical Support & 2 \\
\hline & \multirow{5}{*}{ Distribution and supply } & Access to financial resources & 2 \\
\hline & & Incentives to production practices & 3 \\
\hline & & Institutional purchasing guarantee mechanisms & 2 \\
\hline & & Agility in distribution / supply chain & 3 \\
\hline & & $\begin{array}{l}\text { Approximation between production and } \\
\text { consumption }\end{array}$ & 1 \\
\hline \multirow{7}{*}{$\begin{array}{l}\text { Development of } \\
\text { permanent processes } \\
\text { of education, research } \\
\text { and training in Food and } \\
\text { Nutrition Security }\end{array}$} & \multirow[t]{4}{*}{ Food and nutrition education } & Valuing regional and traditional food culture & 2 \\
\hline & & Environmental Sustainability & 2 \\
\hline & & Encouraging healthy eating habits & 3 \\
\hline & & Advertising & 3 \\
\hline & \multirow[t]{2}{*}{ Research and training } & Promotion of research & 2 \\
\hline & & Permanent education & 3 \\
\hline & Public education system & $\begin{array}{l}\text { Food and Nutrition Security in Political-Pedagogical } \\
\text { Projects }\end{array}$ & 3 \\
\hline \multirow{7}{*}{$\begin{array}{l}\text { Food and nutrition actions } \\
\text { at all levels of health care }\end{array}$} & \multirow[t]{4}{*}{ Basic care } & Food and nutrition surveillance & 3 \\
\hline & & Promotion of adequate and healthy eating habits & 4 \\
\hline & & Prevention and control of health problems & 3 \\
\hline & & Sanitary and Environmental Surveillance & 3 \\
\hline & \multirow[t]{2}{*}{ Medium complexity } & System for non-communicable diseases care & 3 \\
\hline & & Access to special dietary needs & 3 \\
\hline & High complexity & Hospital food assistance & 3 \\
\hline \multirow{3}{*}{$\begin{array}{l}\text { Promotion of universal } \\
\text { access to water }\end{array}$} & \multirow{3}{*}{$\begin{array}{l}\text { Structuring of basic sanitation } \\
\text { systems }\end{array}$} & Programs of access to basic sanitation & 5 \\
\hline & & Promoting the rational use of water resources & 3 \\
\hline & & Conservation and Management of Water Resources & 5 \\
\hline $\begin{array}{l}\text { Traditional peoples and } \\
\text { communities }\end{array}$ & $\begin{array}{l}\text { Prioritization of traditional peoples } \\
\text { and communities }\end{array}$ & $\begin{array}{l}\text { Prioritization of traditional peoples and communities } \\
\text { in all dimensions }\end{array}$ & 3 \\
\hline \multirow{4}{*}{ Evaluation and monitoring } & \multirow{4}{*}{$\begin{array}{l}\text { Evaluation and monitoring of Food } \\
\text { and Nutrition Security Plans }\end{array}$} & Mapping of socially vulnerable families & 2 \\
\hline & & Follow-up on Food and Nutrition Security indicators & 3 \\
\hline & & Monitoring the actions of the plan & 3 \\
\hline & & Reporting channels & 2 \\
\hline
\end{tabular}

between 0.5 and 9.5. In this way, each measure received a score between zero and ten.
From the definition of the grades given for each measure, the other components of the 
evaluative matrix were calculated. The result of the indicator was obtained through the average of the grades given to the measures. The average of the results of the indicators generated the result of each corresponding sub-dimension, being the same procedure adopted in the analysis of the dimensions and in the Plan.

According to Figure 1, a value judgment was given for each component of the matrix, according to the result obtained. If the result was less than five, the component would be considered as bad. If the result was equal or superior to five and less than seven, it would be considered as regular. A score greater than or equal to seven and less than eight and a half would be considered as good and, if the result was equal or superior to eight and a half, it would be considered as excellent.

Data were analyzed using an automated spreadsheet which was made using Microsoft Office Excel $^{\circledR}$ (Microsoft Corp., Redmond, Washington, DC, United States) software, and the results presented in the form of tables indicating the value judgment for each of the matrix components.

\section{RE S U L T S}

The State of Santa Catarina Food and Nutrition Security Plan had 146 goals and 212 actions, distributed in 43 objectives and 8 guidelines [14] that responded to the Food and Nutrition Security guidelines of the National Policy for Food And Nutrition Security [10]. It was prepared by the state Câmara Intersetorial de Segurança Alimentar e Nutricional (CAISAN, Intersectorial Chamber for Food and Nutrition Security) between 2013 and 2014, with the support of an external consultancy, and considered the actions already foreseen in the Pluriannual Plan of the State in force at the time and the proposals from the IV Food and Nutrition Security State Conference held in $2011[1,14]$.

The State of Santa Catarina Food and Nutrition Security Plan was evaluated as of

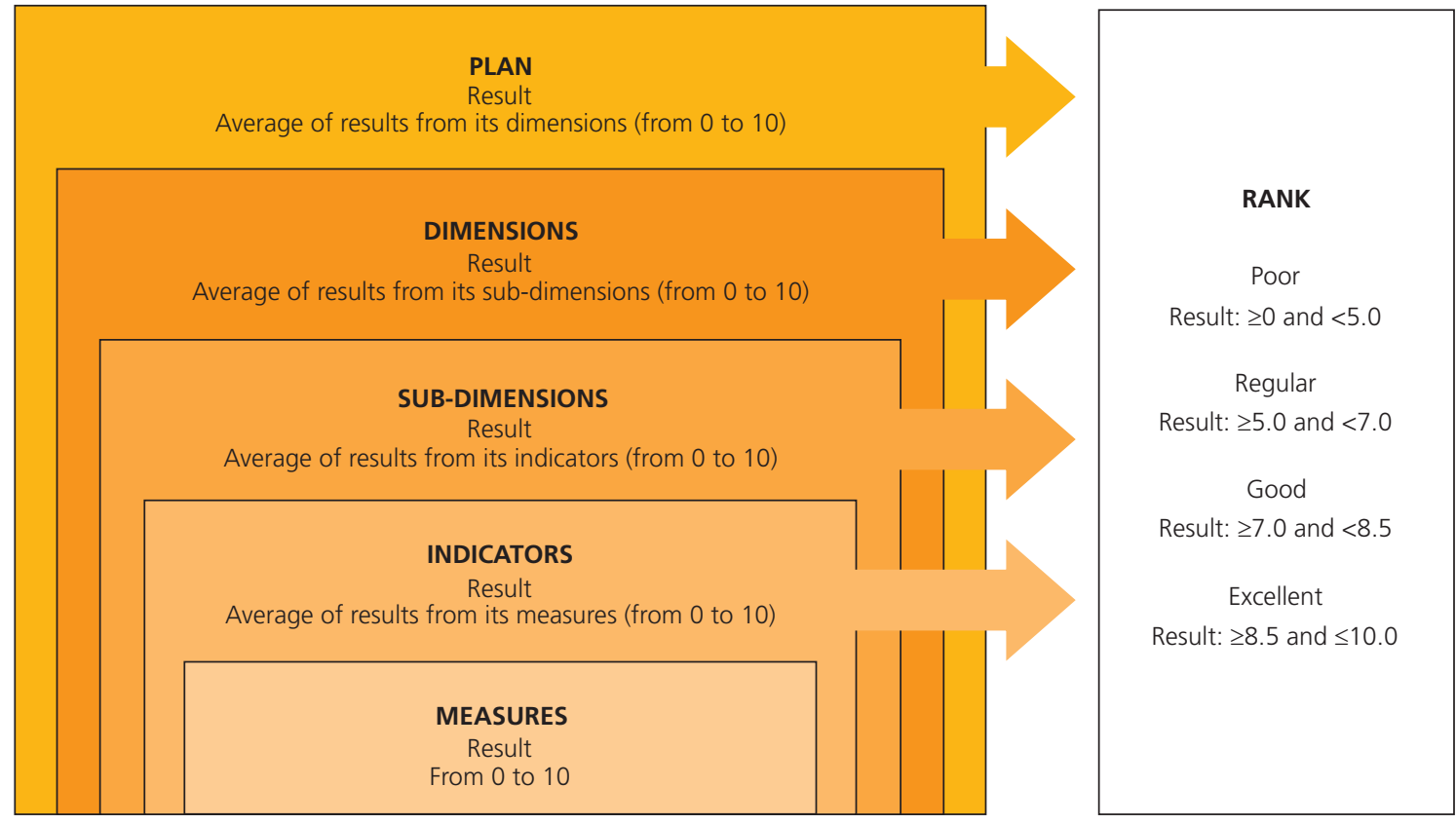

Figure 1. Results and rank of the indicators, sub-dimensions, dimensions of the evaluation model of the State Plans of Food and Nutrition Security. Santa Catarina (SC), Brazil, 2017 
good relevance to the concept of Food and Nutrition Security adopted in Brazil (Table 2). Of the total dimensions analyzed $(n=7)$, the Plan was considered of good relevance to $57 \%(n=4)$ of them and of regular relevance to $43 \%(n=3)$. It presented good relevance to the dimensions of developing permanent processes of education, research and training in Food and Nutrition Security; evaluation and monitoring; structuring agro-ecological production systems and sustainable food supply; and promotion of universal access to water. On the other hand, it had a regular relevance to the dimensions of food and nutrition actions at all levels of health care; traditional peoples and communities; and promotion of universal access to adequate food (Table 2).

As to the sub-dimensions, $19 \% \quad(n=3)$ showed excellent relevance, $31 \% \quad(n=5)$ good

Table 2. Result of the evaluation of pertinence of the State Plan of Food and Nutrition Security, according to sub-dimensions and dimensions. Santa Catarina (SC), Brazil, 2017

\begin{tabular}{|c|c|c|}
\hline Dimensions and Sub-dimensions & Result & Rank \\
\hline Dimension - Promotion of universal access to adequate eating habits & 6.1 & Regular \\
\hline Sub-dimension - Prioritization of populations in situations of social vulnerability & 8.9 & Excellent \\
\hline Sub-dimension - Income & 7.7 & Good \\
\hline Sub-dimension - Tax adjustment & 3.3 & Poor \\
\hline Sub-dimension - Distribution of food and meals & 4.6 & Poor \\
\hline Dimension - Structuring of agroecological production systems and sustainable food supply & 7.3 & Good \\
\hline Sub-dimension - Access to land & 8.3 & Good \\
\hline Sub-dimension - Incentive to production & 5.6 & Regular \\
\hline Sub-dimension - Distribution and supply & 8.1 & Good \\
\hline $\begin{array}{l}\text { Dimension - Development of permanent processes of education, research and training in Food } \\
\text { and Nutrition Security }\end{array}$ & 7.4 & Good \\
\hline Sub-dimension - Food and nutrition education & 6.8 & Regular \\
\hline Sub-dimension - Research and training & 6.7 & Regular \\
\hline Sub-dimension - Public education system & 8.9 & Excellent \\
\hline Dimension - Food and nutrition actions at all levels of health care & 6.8 & Regular \\
\hline Sub-dimension - Basic care & 6.8 & Regular \\
\hline Sub-dimension - Medium complexity & 4.2 & Poor \\
\hline Sub-dimension - High complexity & 9.3 & Excellent \\
\hline Dimension - Promoting universal access to water & 7.0 & Good \\
\hline Sub-dimension - Structuring of basic sanitation systems & 7.0 & Good \\
\hline Dimension - Traditional peoples and communities & 6.7 & Regular \\
\hline Sub-dimension - Prioritization of traditional peoples and communities & 6.7 & Regular \\
\hline Dimension - Evaluation and monitoring & 7.4 & Good \\
\hline Sub-dimension - Evaluation and monitoring of the Food and Nutrition Security Plans & 7.4 & Good \\
\hline Pertinence of the Plan & 7.0 & Good \\
\hline
\end{tabular}


relevance, 31\% $(n=5)$ regular relevance and $19 \%(n=3)$ poor relevance. The Plan presented great relevance to the sub-dimensions of the high complexity of food and nutrition actions in Brazil's Unified Public Health System; prioritization of populations in situations of social vulnerability and the public education system. It was evaluated as poor for the sub-dimensions of tax adjustment; medium complexity of food and nutrition actions in Brazil's Unified Public Health System; and distribution of food and meals (Table 2).

The data presented in Table 3 indicate that the State of Santa Catarina Food and Nutrition Security Plan had an excellent relevance to $26 \%$ $(n=9)$ of the analyzed indicators, good for $14 \%$ $(n=5)$, regular for $46 \% 16)$ and poor for $14 \%$ $(n=5)$.

Agrarian reform; approximation between production and consumption; environmental sustainability were the three indicators to obtain maximum score, demonstrating that the Plan contained goals or actions that fully covered all measures of these indicators (Table 3).

Of the nine indicators whose Plan was of great relevance, three were of the structuring dimension of agroecological production systems and sustainable food supply and two of the development of permanent processes of education, research and training in Food and Nutrition Security. The dimensions of promoting universal access to adequate food; food and nutrition actions at all levels of health care; promotion of universal access to water; and evaluation and monitoring, each had only one indicator, evaluated as of excellent relevance (Table 3).

The State of Santa Catarina Food and Nutrition Security Plans showed poor grades for indicators of access to special dietary needs; fiscal incentives in the production/purchase of adequate food; implementation of food and meal distribution programs; health and environmental surveillance; and promotion of rational use of water resources. Of these indicators, two were related to the promotion of universal access to adequate food, two to food and nutrition at all levels of public health care, and one to universal access to water (Table 3).

The Plan did not describe goals or actions that would, to any degree, meet the guidelines regarding the development of clinical care protocols for special nutritional needs; the distribution of dairy and food formulas according to the health need of the individual; the surtaxation of industrialized foods which are harmful to health; the adaptation of basic food baskets used in social care and civil defense, among other agencies, regarding quality, quantity and food culture; the adequacy of state sanitary legislation to the reality of local production, industrialization and commercialization of foods, giving priority to homegrown and family-produced foods; and monitoring the consumption and volume of water available (Table 3).

\section{DISCUSSION}

This research performed a strategic evaluation to analyze to what degree the State of Santa Catarina Food and Nutrition Security Plan is pertinent to the concept of Food and Nutrition Security adopted in Brazil. The evaluation of social policies and programs gained momentum in the country after the process of re-democratization and, in general, end results were the focus of the interventions. However, while the analysis of the final results of Food and Nutrition Security programs is important, it does not appear to be enough to guide the conduct of the policy and to correct problems. Thus, it is suggested to advance in the traditionally used evaluative strategies, constructing approaches and methodologies that answer for the complexity of the actions involved in the National Policy for Food And Nutrition Security [15].

Among the possibilities of evaluative research, strategic analysis occupies an increasingly 
Table 3. Result of the evaluation of relevance of the State Plan of Food and Nutrition Security according to indicators. Santa Catarina (SC), Brazil, 2017.

\begin{tabular}{|c|c|c|c|}
\hline Indicator & $\begin{array}{c}\mathrm{n}^{\circ} \text { of } \\
\text { measures }\end{array}$ & Result & Rank \\
\hline \multicolumn{4}{|l|}{ Dimension - Promoting universal access to adequate food } \\
\hline \multicolumn{4}{|l|}{ Sub-dimension - Prioritization of populations in situations of social vulnerability } \\
\hline Indicator - Flow of attention to populations in social vulnerability & 3 & 8.9 & Excellent \\
\hline \multicolumn{4}{|l|}{ Sub-dimension - Income } \\
\hline Indicator - Generation of employment and income & 5 & 7.7 & Good \\
\hline \multicolumn{4}{|l|}{ Sub-dimension - Tax adjustment } \\
\hline Indicator - Tax incentive in the production/purchase of adequate food & 3 & 3.3 & Poor \\
\hline \multicolumn{4}{|l|}{ Sub-dimension - Distribution of food and meals } \\
\hline Indicator - Implementation of food and meal distribution programs & 4 & 4.1 & Poor \\
\hline Indicator - Availability of public equipment related to Food and Nutrition Security & 2 & 5.0 & Regular \\
\hline \multicolumn{4}{|l|}{ Dimension - Structuring of agroecological production systems and sustainable food supply } \\
\hline \multicolumn{4}{|l|}{ Sub-dimension - Access to land } \\
\hline Indicator - Landholding and land regulation & 2 & 6.7 & Regular \\
\hline Indicator - Agrarian reform & 1 & 10.0 & Excellent \\
\hline \multicolumn{4}{|l|}{ Sub-dimension - Incentive to production } \\
\hline Indicator - Qualification and Technical Support & 2 & 5.0 & Regular \\
\hline Indicator - Access to financial resources & 2 & 6.7 & Regular \\
\hline Indicator - Incentives for production practices & 3 & 5.0 & Regular \\
\hline \multicolumn{4}{|l|}{ Sub-dimension - Distribution and supply } \\
\hline Indicator - Institutional purchasing guarantee mechanisms & 2 & 5.0 & Regular \\
\hline Indicator - Agility in distribution/supply chain & 3 & 9.2 & Excellent \\
\hline Indicator - Approximation between production and consumption & 1 & 10.0 & Excellent \\
\hline
\end{tabular}

Dimension - Development of permanent processes of education, research and training in Food and Nutrition Security

Sub-dimension 3.1 - Food and nutritional education

Indicator - Valuation of regional and traditional food culture

Indicator - Environmental Sustainability

2

Indicator - Stimulating healthy eating habits

Indicator - Advertising

Sub-dimension - Research and training

Indicator - Promotion of research

Indicator - Permanent education

Sub-dimension - Public education system

Indicator of Food and Nutrition Security in Political-Pedagogical Projects

\section{2}

3

3

2

3

3
Dimension 4 - Food and nutrition actions at all levels of health care

Sub-dimension - Basic care

Indicator - Food and nutrition surveillance

Indicator - Promotion of adequate and healthy nutrition habits

Indicator - Prevention and control of health problems

Indicator - Health and environmental surveillance

$\begin{aligned} 5.0 & \text { Regular } \\ 10.0 & \text { Excellent } \\ 5.5 & \text { Regular } \\ 6.7 & \text { Regular } \\ & \\ 6.7 & \text { Regular } \\ 6.7 & \text { Regular }\end{aligned}$

8.9 Excellent 
Table 3. Result of the evaluation of relevance of the State Plan of Food and Nutrition Security according to indicators. Santa Catarina (SC), Brazil, 2017

\begin{tabular}{lccc}
\hline Indicator & $\begin{array}{c}\mathrm{n}^{\circ} \text { of } \\
\text { measures }\end{array}$ & Result & Rank \\
\hline Sub-dimension - Medium complexity & & & Regular \\
Indicator - Organization of non-communicable diseases care & 3 & 6.7 & Poor \\
Indicator - Access to special food needs & 3 & 1.7 & Excellent \\
Sub-dimension - High complexity & & 3 & 9.3
\end{tabular}

Dimension - Promoting universal access to water

Sub-dimension - Structuring of basic sanitation systems

Indicator - Access programs to basic sanitation

Indicator - Promotion of rational use of water resources

Indicator - Conservation and Management of Water Resources

$3 \quad 4.4 \quad$ Poor

$5 \quad 9.3 \quad$ Excellent

Dimension - Traditional peoples and communities

Sub-dimension - Prioritization of traditional peoples and communities

6.1.1 Prioritization of traditional peoples and communities in all dimensions

3

6.7 Regular

Dimension - Evaluation and monitoring

Sub-dimension - Evaluation and monitoring of Food and Nutrition Security plans

7.1.1 Mapping of socially vulnerable families

7.1.2 Monitoring of Food and Nutrition Security indicators

7.1.3 Monitoring the actions of the plan

7.1.4 Reporting channels

\begin{tabular}{lll}
2 & 6.3 & Regular \\
3 & 7.8 & Good \\
3 & 6.7 & Regular \\
2 & 8.8 & Excellent \\
\hline
\end{tabular}

important place, for it returns to the planning stage, verifying if any actions were taken regarding the most pertinent factors, considering the importance of these on the matter [11].

The Food and Nutrition Security Plans gather objectives, goals, and actions of the intervention proposed by the management to address Food and Nutrition Security issues. In this context, Food and Nutrition Security Plans evaluated as being of good relevance to the Food and Nutrition Security concept point to a greater possibility that, if their goals and actions are properly implemented, they can improve the situation of Food and Nutrition Security in the state.

However, in the case of the researched Plan, the fact that the analyzed dimensions presented differences in the evaluation demonstrates a limit to overcome the sectorization of public management, which constitutes a challenge in the face of the complexity of a concept that involves innumerable dimensions related to quantity, but mainly to the quality of food consumed [16]. Given the inherently intersectoral nature of the National System of Food and Nutrition Security [17], being able to diagnose the demands of Food and Nutrition Security in the territory, as well as thinking strategies to overcome them, presupposes a collective effort of several sectors of society and government [18]. Thus, the construction of an intersectorial action depends on a sharing of knowledge from several sectors and, consequently, on the involvement of countless individuals in this process [19]. 
The evaluation and monitoring dimensions and the development of permanent processes of education, research and training in Food and Nutrition Security, were highlighted as the ones that obtained the best result. The former concerns monitoring the execution of the Plan, as well as the processes that allow an evaluation of the value of the results from this action. In addition to its logical importance, this dimension also has a normative relevance, since the legislation of the National System of Food and Nutrition Security determines that the Food and Nutrition Security Plan should describe the ways of monitoring and evaluating the execution of their actions, compliance with goals and monitoring of results [9]. Thus monitoring and evaluation procedures should be put in place for the plan, but also for Food And Nutrition Security. The State of Santa Catarina Food and Nutrition Security Plans contemplated goals and actions for indicators related to the establishment of channels for reporting violations of the Human Right to Adequate Food, strengthening information systems and monitoring the implementation of the Plan. Even so, it is possible to qualify this dimension from its inclusion in the Plan of actions and goals responsible for mapping families in situation of social vulnerability. By prioritizing resources to address inequities, it is expected a more efficient management tool, and committed to ensuring the right to food for the population groups that need it the most [20].

The other dimension with a good score refers to the guarantee of universal access to education, to permanent processes of food and nutrition education, and to value research and training in Food and Nutrition Security. Universal access to education, based on a democratic ideology, is fundamental to attenuate the historically established differences in a classdivided society, thus allowing everyone to enjoy, without distinction, social rights [21]. In the context of the Human Right to Adequate Food, food and nutrition education aims to promote the autonomous and voluntary practice of healthy eating habits [22] and is an important strategy to address health, food and nutrition challenges [23]. In addition, strengthening the strategies for guaranteeing the Human Right to Adequate Food and formulating and implementing policies of Food And Nutrition Security depends on the continuous qualification of technical and scientific knowledge, with training of different social actors $[24,25]$.

Despite the good relevance to the precepts of this dimension, the indicator of valuing regional and traditional food culture, belonging to the sub-dimension of "food and nutrition education", was evaluated as regular. The process of globalization of food and homogenization of food standards tends to undermine food sovereignty and reduce people's autonomy to produce and consume food, as well as to preserve their food history and tradition $[26,27]$. Such aspects are among the main causes of food and nutritional insecurity and, therefore, strategies for overcoming them are a priority [28].

The structuring of agroecological production systems and sustainable food supply was the third dimension with the best result. It concerns the first stage of the human food chain, involving issues related to access to land, production and distribution of food $[29,30]$.

Until the end of the nineteenth century, hunger was understood as a natural phenomenon, a result of population growth, higher than the capacity for food production. With the strengthening of the capitalist economy and industrialization in the mid-nineteenth century, this conception was used to justify public and private investment in actions that resulted in an increase in agricultural production. Environmentally predatory production methods, supported by latifundia, monoculture, extensive use of agricultural poisons, mechanization of crop production, and rural exodus became hegemonic [31,32]. However, in the last decades, the debate over production forms 
that were able to meet the food demand of the population in a healthy way and which were environmentally, economically and socially sustainable has expanded, assuming that the agroecological production model meets these conditions. Within an agroecological production system, organic production by family farmers, supported by solidarity economy mechanisms, takes a leading role $[33,34]$.

The State of Santa Catarina Food and Nutrition Security Plans were evaluated as good or excellent in the indicators related to landholding and land regularization, agrarian reform, access to financial resources, agility in the supply chain/distribution, and the approximation of production and consumption. However, the indicators of qualification and technical support, incentive to production practices and mechanisms that guarantee institutional purchases were evaluated as regular, indicating the need to qualify the goals and actions related to these topics.

The fourth dimension that was best evaluated was the promotion of universal access to water, which refers to the proper quality and quantity to meet the daily dietary needs and food production. The lack of goals and actions in the State of Santa Catarina Food and Nutrition Security Plan regarding the promotion of the rational use of water resources was determining to prevent this dimension from being evaluated as excellent. Culturally, huge volumes of water are wasted throughout the food production and consumption chain. Only in situations of severe drought and water insecurity strategies for waste reduction are discussed [35]. In this sense, Food and Nutrition Security Plans need to encourage educational actions regarding the rational use of water resources, as well as develop preventive actions in the distribution network.

The dimension of food and nutrition actions at all levels of health care was among the top three worst performing. It involves the relation of promotion, prevention and assistance strategies in the three levels of care in Brazil's Unified Public
Health System. In an epidemiological context of high prevalence of obesity and chronic diseases associated with malnutrition, coexisting with micronutrient deficiency diseases and persistent cases of malnutrition [36], food and nutrition actions in the health sector should be strengthened [37]. The state of Santa Catarina Food and Nutrition Security Plans presented the goals and actions of hospital food assistance and promotion of adequate and healthy food as potentialities. However, it has shown fragility in relation to sanitary and environmental surveillance, and especially in guaranteeing access to special dietary needs. An expressive portion of the Brazilian population demands special dietary needs, however, they remain invisible and/or secondary in the health care agenda. The construction and the guarantee of qualified care to people with these necessities must be assumed as fundamental for the construction of fairness in health care [38].

The dimension of traditional peoples and communities was the second worst evaluated, showing fragility in the prioritization of these in all other dimensions of the Plan. The National System of Food and Nutrition Security legislation states that Food and Nutrition Security Plans should incorporate strategies with attention to the various population groups in situations of vulnerability, and food and nutrition insecurity, prioritizing traditional peoples and communities. This prioritization occurs due to a historical marginalization and denial, in public policies, of their traditions and food practices. In addition, a lack of land tenure, a lack of income, a substantial increase of diseases, marginality, illiteracy and lack of infrastructure are factors that characterize food insecurity for these peoples [39].

The worst-performing dimension was the promotion of universal access to adequate food. Among the main weaknesses were the availability of public Food and Nutrition Security tools, the implementation of food and meal distribution programs, and tax incentives to the production/consumption of adequate food. This 
dimension deserves to be highlighted in the Food and Nutrition Security concept, since hunger as a result of the impossibility of access to food is still the main problem, being responsible for inserting other issues in the agenda [40]. It is accepted that the Brazilian nutritional transition justifies a greater concern in the development of strategies to overcome problems related to inadequate eating habits, but this movement should not deny the worrying existence of populations who are still suffering from poverty and hunger. In addition, reducing the incidence and prevalence of chronic diseases associated with food is also dependent on actions that ensure and expand access to adequate and healthy food $[41,42]$. This context reinforces the importance of Food and Nutrition Security Plans to broaden or qualify their goals and actions to this dimension.

\section{O N CLUSION}

This research identified a good relevance of the State of Santa Catarina Food and Nutrition Security Plan to the concept of Food and Nutrition Security adopted in Brazil. The results found for the dimensions of developing of permanent processes of education, research and training in Food and Nutrition Security; evaluation and monitoring; structuring agroecological production systems and sustainable food supply, and promoting universal access to water were positively highlighted. The dimension of promotion of universal access to adequate food achieved the worst result, stressing the need to build or qualify goals and actions that respond to the availability of public service Food and Nutrition Security tools, the execution of food and meal distribution programs, and tax incentives to the production/consumption of adequate food.

This research represents the reality of the Food and Nutrition Security Plan of a state in Brazil. Nevertheless, considering that all the states have adhered to the National System of Food and Nutrition Security and, therefore, have gone or will go through the process of construction and evaluation of their Food and Nutrition Security Plan, it is believed that the results and the proposed reflections can stimulate actions in different contexts. It is hoped that the results may guide the construction and qualification of other state plans and, consequently, qualify the National Policy for Food and Nutrition Security, enhancing its results. Still, given the need to deepen the evaluations on the structure, process and result of the public policies of Food and Nutrition Security, it is suggested to carry out complementary researches to evaluate the efficiency and the effectiveness of the interventions in Food and Nutrition Security.

\section{CONTRIBUTORS}

ML MACHADO participated in the idealization and design of the study, and the analysis and interpretation of the data. CG GABRIEL participated in the idealization and design of the study. All authors participated in the review and final approval of the article.

\section{R E F E R E N C E S}

1. Machado ML, Gabriel CG, Soar C, Mamed GR, Machado PMO, Lacerda JT, et al. Adequação normativa dos Planos Estaduais de Segurança Alimentar e Nutricional no Brasil. Cad Saúde Pública. 2018;34(1):e00206716. http://dx.doi.org/10. 1590/0102-311X00206716

2. Pessanha LDR. A experiência brasileira em políticas públicas para a garantia do direito ao alimento. Rio de Janeiro: IBGE; 2002 [acesso 2017 jun 18]. Disponível em: https://biblioteca.ibge.gov.br/ visualizacao/livros/liv1645.pdf

3. Kepple AW, Segall-Corrêa AM. Conceituando e medindo segurança alimentar e nutricional. Ciênc Saúde Coletiva. 2011;16(1):187-99. http://dx.doi. org/10.1590/S1413-81232011000100022

4. Instituto Brasileiro de Geografia e Estatística. Pesquisa Nacional por Amostra de Domicílio: Segurança Alimentar - 2004/2009. Rio de Janeiro: IBGE; 2010.

5. Corrêa AMS. Insegurança alimentar medida a partir da percepção das pessoas. Estud Av. 
2007;21(60):143-54. http://dx.doi.org/10.1590/S0 103-40142007000200012

6. Panelli-Martins BE, Santos SMC, Assis AMO. Segurança alimentar e nutricional: desenvolvimento de indicadores e experimentação em um município da Bahia, Brasil. Rev Nutr. 2008;21(Suppl.):65s-81s. http://dx.doi.org/10.15 90/S 1415-52732008000700007

7. Costa LV, Gomes MFM, Lelis DAS. Food security and agricultural productivity in Brazilian metropolitan regions. Procedia Econ Financ. 2013;5:202-11. http://dx.doi.org/10.1016/S2212-5671(13)000 26-9

8. Valente FLS. Fome, desnutrição e cidadania: inclusão social e direitos humanos. Saúde Soc. 2003 [acesso 2017 jun 18];12(1):51-60. Disponível em: http://www.scielo.br/pdf/sausoc/v12n1/08.pdf

9. Brasil. Presidência da República. Decreto n 7.272, de 25 de agosto de 2010. Regulamenta a Lei $n^{\circ}$ 10.346, de 15 de setembro de 2006, que cria o Sistema Nacional de Segurança Alimentar e Nutricional - SISAN com vistas a assegurar o Direito Humano à Alimentação Adequada, institui a Política Nacional de Segurança Alimentar e Nutricional - PNSAN, estabelece os parâmetros para a elaboração do Plano Nacional de Segurança Alimentar e Nutricional, e dá outras providências. Brasília: Casa Civil; 2010 [acesso 2017 jun 18]. Disponível em: http://www.planalto.gov.br/ccivil_03/_ ato2007-2010/2010/decreto/d7272.htm

10. Rigon SA, Schmidt ST, Bógus CM. Desafios da nutrição no Sistema Único de Saúde para construção da interface entre a saúde e a segurança alimentar e nutricional. Cad Saúde Pública. 2016;32(3):e00164514. http://dx.doi.org/10.1590/0 102-311X00164514

11. Champagne F. A avaliação no campo da saúde: conceitos e métodos. In Brousselle A, Champagne F. Avaliação: conceitos e métodos. Rio de Janeiro: Fiocruz; 2011. p.291.

12. Contandriopoulos A-P. Avaliando a institucionalização da avaliação. Ciênc Saúde Coletiva. 2006;11(3):705-11. http://dx.doi.org/10.1590/s14 $13-81232006000300017$

13. Jorm AF. Using the Delphi expert consensus method in mental health research. Aust N Z J Psychiatry. 2015;49(10):887-97. http://dx.doi.org/10. 1177/0004867415600891

14. Câmara Intersetorial de Segurança Alimentar e Nutricional (Santa Catarina). Plano Estadual de Segurança Alimentar e Nutricional: Santa Catarina 2014-2019. Florianópolis: Governo de Santa Catarina; 2014.

15. Magalhães R. Avaliação de políticas e iniciativas públicas de segurança alimentar e nutricional: dilemas e perspectivas metodológicas. Ciênc Saúde Coletiva. 2014;19(5):1339-46. http://dx.doi. org/10.1590/1413-81232014195.12202013

16. Costa CA, Bógus CM. Significados e apropriações da noção de segurança alimentar e nutricional pelo segmento da sociedade civil do Conselho Nacional de Segurança Alimentar e Nutricional. Saúde Soc. 2012;21(1):103-14. http://dx.doi.org/10. 1590/S0104-12902012000100011

17. Burlandy L. A construção da política de segurança alimentar e nutricional no Brasil: estratégias e desafios para a promoção da intersetorialidade no âmbito federal de governo. Ciênc Saúde Coletiva. 2009;14(3):851-60. http://dx.doi.org/10.1590/S14 13-81232009000300020

18. Rocha NC, Doria NG, Boia JM, Bógus CM. Organization and dynamics of Conselho Municipal de Segurança Alimentar e Nutricional de São Paulo: Implications of their participation on the creation of a municipal food and nutrition security policy. Rev Nutr. 2012;25(1):133-46. http://dx.doi. org/10.1590/S1415-52732012000100012

19. Monnerat GL, Souza R. Política social e intersetorialidade: consensos teóricos e desafios práticos. Ser Social. 2009 [acesso 2017 jun 18];12(26):200-20. Disponível em: http://periodicos.unb.br/index.php/ SER_Social/article/view/1023

20. Vieira VL, Souza JMP, Cervato-Mancuso AM. Insegurança alimentar, vínculo mãe-filho e desnutrição infantil em área de alta vulnerabilidade social. Rev Bras Saúde Mater Infant. 2010;10(2):199-207. http://dx.doi.org/10.1590/S15 19-38292010000200007

21. Singer P. Poder, política e educação. Rev Bras Educ. 1996 [acesso 2017 jun 18];1(1):5-15. Disponível em: http://www.ia.ufrrj.br/ppgea/conteudo/ T2-1SF/Sandra/Poder, \%20pol\%EDtica\%20e\%20 educa\%E7\%E3o.pdf

22. Brasil. Ministério do Desenvolvimento Social. Marco de referência de educação alimentar e nutricional para as políticas públicas. Brasília: Ministério do Desenvolvimento Social; 2012 [acesso 2017 jun 18]. Disponível em: https:// www.ideiasnamesa.unb.br/files/marco_EAN_ visualizacao.pdf

23. Silva Santos LA. O fazer educação alimentar e nutricional: algumas contribuições para reflexão. Ciênc Saúde Coletiva. 2012;17(2):455-62. http://dx. doi.org/10.1590/S1413-81232012000200029

24. Anjos LA, Burlandy L. Construção do conhecimento e formulação de políticas públicas no Brasil na área de segurança alimentar. Ciênc Saúde Coletiva. 2010;15(1):19-23. http://dx.doi. org/10.1590/S1413-81232010000100003 
25. Bosi MLM. Desafios na interface pesquisa-construção do direito humano à alimentação: reflexões no âmbito da segurança alimentar e nutricional. Ciênc Saúde Coletiva. 2010;15(1):22-4. http://dx. doi.org/10.1590/S1413-81232010000100004

26. Oliveira AU. A mundialização do capital e a crise do neoliberalismo: o lugar mundial da agricultura brasileira. GeoUSP. 2015;19(2):228-44. http:// dx.doi.org/10.11606/issn.2179-0892.geousp. 2015.102776

27. Goldfarb Y. A agricultura a partir do neoliberalismo: financeirização, poder corporativo e as ameaças à soberania alimentar. Agrária. 2012;(17):42-58. http://dx.doi.org/10.11606/issn.1808-1150.v0i17 $p \% 25 p$

28. Marques PEM. Embates em torno da segurança e soberania alimentar: estudo de perspectivas concorrentes. Segur Alim Nutr. 2010;17(2):78-87. http://dx.doi.org/10.20396/san.v17i2.8634795

29. Alencar ÁG. Do conceito estratégico de segurança alimentar ao plano de ação da FAO para combater a fome. Rev Bras Polít Inter. 2001;44(1):137-44. http://dx.doi.org/10.1590/S00 34-73292001000100009

30. Belton B, Thilsted SH. Fisheries in transition: Food and nutrition security implications for the global South. Glob Food Sec. 2014;3(1):59-66. http:// dx.doi.org/10.1016/j.gfs.2013.10.001

31. Moreira RJ. Críticas ambientalistas à revolução verde. Estud Soc Agric. 2000 [acesso 2017 jun 18];(15):39-52. Disponível em: http://r1.ufrrj.br/ esa/N2/ojs/index.php/esa/article/view/176

32. Albergoni L, Pelaez V. Da revolução verde à agrobiotecnologia: ruptura ou continuidade de paradigmas? Rev Econ. 2007;33(1):31-53. http:// dx.doi.org/10.5380/re.v33i1.8546

33. Caporal FR, Costabeber JA. Segurança alimentar e agricultura sustentável: uma perspectiva agroecológica. Ciênc Ambiente. 2006 [acesso 2017 jun 18];1(1):153-65. Disponível em: http:// plataforma.cpacp.embrapa.br/mostrar_pdf.php? search $=106$

34. Dubeux A, Batista MP. Agroecologia e economia solidária: um diálogo necessário à consolidação do direito à soberania e segurança alimentar e nutricional. Redes. 2017;22(2):227-49. http://dx. doi.org/10.17058/redes.v22i2.9340

35. Tundisi JG, Tundisi TM. As múltiplas dimensões da crise hídrica. Rev USP. 2015;106:21-30. http://dx. doi.org/10.11606/issn.2316-9036.v0i106p21-30

36. Souza EB. Transição nutricional no Brasil: análise dos principais fatores. Cad UniFOA. 2010 [acesso 2017 jun 18];5(13):49-53. Disponível em: http:// web.unifoa.edu.br/cadernos/edicao/13/49.pdf

37. Jaime PC, Santos LMP. Transição nutricional e a organização do cuidado em alimentação e nutrição na Atenção Básica em saúde. Divulg Saúde Debate. 2014 [acesso 2017 jun 18];(51):72-85. Disponível em: http://pesquisa.bvsalud.org/ripsa/ resource/pt/lil-771500

38. Castro LMC, Castro IRR. Necessidades alimentares especiais: o cuidado e a busca da equidade na atenção à saúde. Demetra. 2014;9(Supl.1):197-8. http://dx.doi.org/10.12957/demetra.2014.11953

39. Silva D, Guerrero AFH, Guerrero CH, Toledo LM. A rede de causalidade da insegurança alimentar e nutricional de comunidades quilombolas com a construção da rodovia BR-163, Pará, Brasil. Rev Nutr. 2008;21(Suppl.):83s-7s. http://dx.doi. org/10.1590/S1415-52732008000700008

40. Pinheiro ARO, Carvalho MFCC. Transformando o problema da fome em questão alimentar e nutricional: uma crônica desigualdade social. Ciênc Saúde Coletiva. 2010;15(1):121-30. http://dx. doi.org/10.1590/S1413-81232010000100018

41. Brasil. Ministério da Saúde. Decreto n 8.553, de 3 de novembro de 2015. Institui o Pacto Nacional para Alimentação Saudável. Brasília: Ministério da Saúde; 2015 [acesso 2017 jun 18]. Disponível em: http://www.planalto.gov.br/ccivil_03/_Ato2015-20 18/2015/Decreto/D8553.htm

42. Malta D, Neto OM, Junior JS. Presentation of the strategic action plan for coping with chronic diseases in Brazil from 2011 to 2022. Epidemiol Serv Saúde. 2011;20(4):425-38. http://dx.doi.org/10. 5123/S1679-49742011000400002

Received: January 4, 2018 Final version: July 5, 2018 Approved: October 17, 2018 